IRA-International Journal of Management \&

Social Sciences

ISSN 2455-2267; Vol.11, Issue 03 (June 2018)

Pg. no. 128-133.

Institute of Research Advances

http://research-advances.org/index.php/RAJMSS

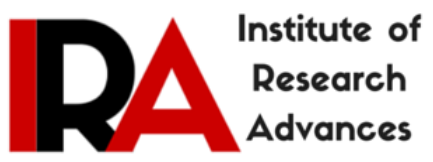

\title{
Muslim Education in Murshidabad, a Bengal District during 1704-1947: A Review
}

\section{Emili Rumi}

Assistant Professor, Sripat Singh College, Jiaganj, Murshidabad, West Bengal, India.

Type of Review: Peer Reviewed.

DOI: http://dx.doi.org/10.21013/jmss.v11.n3.p3

\section{How to cite this paper:}

Rumi, E. (2018). Muslim Education in Murshidabad, a Bengal District during 1704-1947: A Review. IRAInternational Journal of Management \& Social Sciences (ISSN 2455-2267), 11(3), 128-133. doi:http://dx.doi.org/10.21013/jmss.v11.n3.p3

(C) Institute of Research Advances.

\section{(cc) $\mathrm{BY}$-NC}

This work is licensed under a Creative Commons Attribution-Non Commercial 4.0 International License subject to proper citation to the publication source of the work.

Disclaimer: The scholarly papers as reviewed and published by the Institute of Research Advances (IRA) are the views and opinions of their respective authors and are not the views or opinions of the IRA. The IRA disclaims of any harm or loss caused due to the published content to any party.

Institute of Research Advances is an institutional publisher member of Publishers Inter Linking Association Inc. (PILA-CrossRef), USA. The institute is an institutional signatory to the Budapest Open Access Initiative, Hungary advocating the open access of scientific and scholarly knowledge. The Institute is a registered content provider under Open Access Initiative Protocol for Metadata Harvesting (OAI-PMH).

The journal is indexed \& included in WorldCat Discovery Service (USA), CrossRef Metadata Search (USA), WorldCat (USA), OCLC (USA), Open J-Gate (India), EZB (Germany) Scilit (Switzerland), Airiti (China), Bielefeld Academic Search Engine (BASE) of Bielefeld University, Germany, PKP Index of Simon Fraser University, Canada. 


\begin{abstract}
The historic city of Murshidabad-the earstwhile nawabi capital - a city founded in the year 1704 by Murshid Quli Khan, the Mughal diwan of Bengal. In 1704 Murshid Quli Khan transferred the capital of Bengal from Dhaka to Murshidabad and named the city after his name.The town is situated on the left bank of river Bhagirathi. It is the northern most district of the Presidency Division of West Bengal and lies between 230 43' and 24 o 52' north latitude and 870 49' and 880 44' east longitude. ' Under the Nawabs Murshidabad's glory reached to the highest peak in almost all arenas. As a trading centre Murshidabad became famous. Many scholars came here and settled and they mixed with the local people freely and there developed a cosmopolitan culture. According o Sushil Chaudhury "It was a golden day of Murshidabad under the Nawabs",.2By the middle of the $18^{\text {th }}$ century Murshidabad became one of the greatest centre of culture and education as the nawabs were the patrons of learned persons. But after the battle of Plassey the scenario of Murshidabad started changing. With the establishment of the British power we see gradual decline of its culture and education. Many of the British policies directly affected Murshidabad such as the shifting of court to Calcutta, introduction of permanent settlement, introduction of western education and declaration of English as the official language instead of Persian. Murshidabad is the only district of West Bengal where Muslims outnumbered the Hindus since 1901 and formed the majority community. Presently this district is a backward district of West Bengal. When we enquire the causes of this backwardness we find education as one of the major causes. The present paper is a modest attempt to analyse the educational progress in Murshidabad under the Nawabs and also under the British. The paper will also enquire the causes of educational backwardness of this district.
\end{abstract}

Keywords: Education, Muslim Education, Murshidabad.

Education is the only mechanism that enhances the process of social, economic, and cultural development of communities. Among all the religious communities, Muslims are in the least educated section of Indian Society. In West Bengal this condition is more pathetic than other states. Among all the districts of West Bengal the status of Muslims in Murshidabad is greatly noticeable to all. To make a deep analysis of the educational progress in Murshidabad first I would like to discuss the education under the Nawabs of Murshidabad .The Nawabs were patrons of learned persons. Some of the Nawabs themselves were very learned .Nawab Murshid Quli Khan raised the stipend for the learned men and vastly religious persons. It is said that he was the patron of some 2500 karri(who read Quran) and the other persons who were engaged in virtuous works. ${ }^{3}$ Nawab Alivardi himself was a great scholar and a great orator also. He was also a great patron of scholars. He made arrangement of scholarly discussion with the cultured persons. During his time Islamic knowledge, Persian as a language and other streams of study such as Mathematics, Astronomy etc. flourished. Jayer Hussain Khan, Taki Quli Khan, Ali Ibrahim, Haji Mohammmad Khan,Mir Muhammmad Ali Fazil were some of the scholars who brightened Alivardi's court. ${ }^{4}$ Mir Mohammmad Ali had a big library of his own which possessed around 2000 books. And Nawab Alivardi showed a great reverence to Mir Mohammmad Ali. Some great physicians adorned the Nawab's court. Among them were Hakim Tajuddin, Hakum Hadi Ali Khan Alivardi had immense confidence on Hakim Hadi Ali Khan and he had great admiration for his Hakim. We see some of the great historians of the age who adorned the court of the Nawabs. Yusuf Ali, Ghulam Hussain Khan Tabatabai, Karam Ali were some of the great historians of the period of our study.

All through the Nawabi period Bengali literature also flourished .The learned men of this period completed a great contribution in Urdu, Hindi, Persian literature. We should mention the Sufi literature of his period .For the expansion of Islam Sufi litterateurs wrote books in Bengali to make the common men understanding the Islamic knowledge and education. This proves that the state of education under the nawabs was good. ${ }^{5}$ During this period a different stream of Bengali language arose here which is called as Musalmani

\footnotetext{
${ }^{1}$ Malley,L.S.S.O' Bengal District Gazetteers ,Murshidabad, Higher Education Department, Govt, of West Bengal ,Calcuta,1997,pp 12.

${ }^{2}$ Chaudhury, Sushil, Nababi Amale Murshidabad,Ananda Publishers, Kolkata 2011,pp 148

${ }^{3}$ Karim ,Abdul,Murshid Quli Khan And His Times, pp 238 quoted in M. A. Rahim's Banglar Samajik O Sanskrit Itihas, Bangla Academy ,Dhaka,1982 translaed by Moh. Asaduzzaman and Fazle Rabbi ,pg209

${ }^{4}$ Rahim,M.A., Banglar Samajik O Sanskrit Itihas, Bangla Academy, Dhaka,1982 bengali translation by Moh. Asaduzzaman and Fazle Rabbi , pg.210

${ }^{5}$ M. A. Rahim, Banglar Samajik O Sanskrit Itihas, Bangla Academy ,Dhaka,9182 translaed by Moh. Asaduzzaman and Fazle Rabbi, pg 212
} 
Bangla which is a mixed of Peresian, Urdu and Bengali languages. A different form of literature arose out of these mixed languages which was popular among the lower section of the society. ${ }^{6}$ The higher section was less influenced by this literature. Persian was the official language of that time. Both the Muslims and Hindus practiced this language as this gave them the opportunity for a job in the government departments. Under the nawabs Murshidabad gained eminent position in the fields of education and culture. Ghulam Hussain gives a long list of learned men, physicians, mathematicians and other scholarly persons. And from this we can assume that educational institutions were there at Murshidabad during the period of review .Murshid Quli Khan established a Madrasha for the uplift of education. This institution was known as Kara Madrasha as it was used as a guest house also and was maintained by the nawab. ${ }^{7}$

But we can say that there was no organised system of education during this time. The whole educational system was maintained only by the personal interests and incentive of the nawabs, zamindars and aristocrats. There were Pathshalas and Tolbakhana for both the Muslim and Hindu students. There were Maqtabs abd Madrashas for the Muslim students and there were Toll and Chatusphathis for the Hindu students. ${ }^{8}$ Muslim educational system roused with the patronage of the nawabs and other well-off Mussalmans. Maqtabs were only for the Muslim boys .The teachers of this Maqtabs were known as Akhunji .They taught Arabic,Urdu and Persian .They also taught primary Mathematics and also gave Islamic education to the students. The students used banana palm leaf and also indigenous paper for writing. After completion of primary education most of the students joined their family jobs and some took of cultivation as their livelihood. Brilliant and ambitious students often went to Madrashas for higher education. The Madrashas were mainly adjacent to the Masjid or Imambara and all were maintained by the govt financial assistance. Tax free lands were also given to these institutions to run the educational system. Apart from this, stipends were also given. The students were given the facility of free lodging and food in the Madrashas and they did not have to pay anything for their education. The maulavis and the learned men of Islamic knowledge were there to give education. The pass out students got government jobs and some went for teaching. Girls of the lower section did not go to the Madrashas or even to the Maqabs. But the upper class Muslim girls could avail education at home. ${ }^{9}$ We find some ladies from the royal family were highly educated, even they played active part in the administration, for example daughter of Murshid Quli Khan Jinnatunnessa, wife of Alivardi Khan Sarfunnessa. ${ }^{10}$

So we can see that under the nawabs Murshidabad obtained a high place in the field of education and culture. The system of education was traditional, only the knowledge of Shariat was given and the higher section could avail that education. The lower section or the common men were away of this educational system. Now we will perceive the educational condition after the British power was established. After the battle of Plassey Murshidabad started losing its glory. Gradually its economic affluence and solvency vanished. Education and culture suffered a reverse and social life of the people headed an abyss. After the establishment of the British power Calcutta started gaining importance as a trading centre for its communication and for many other reasons. All the important offices were shifted to Calcutta from Murshidabad. The East India Company started implementing their own rules in every sphere of administration. They wanted to introduce Western education to run their rule in India as they needed some Indian clerks. The Muslims did not accept the Western education as they considered the British as infidels. As a result they lagged behind and the Hindus who accepted the Western education went ahead. It is well known factor that this non acceptance of Western education is one of the reasons that the Muslim community is a backward community all over India. To analyse the educational progress in Murshidabad under the British rule first we should discuss the role of Nizamat College in extending the western education. On $31^{\text {st }}$ August, 1824 William Lock, the agent of the governor of India intended to establish a school and a college for the youths of the Nawab family. He wanted to amend the corruption and

\footnotetext{
${ }^{6}$ Basak, Nrittalal History of Venacular Educatin in Bengal ,Ph.D. thesis -quoted in Das, Debashree, Musrshidabad Jelai Sanskritik Mukttodhara: Oiihasik Samikka, Prabha Prakasani,24 Parganas,2002,pg 62

${ }^{7}$ Karim , Abdul ,Murshid Quli Khan And His Times, pp 238 quoted in M. A. Rahim Banglar Samajik O Sanskrit Itihas, Bangla Academy ,Dhaka, 9182 translaed by Moh. Asaduzzaman and Fazle Rabbi ,pg242

${ }^{8}$ Mukhopadhya, Subodh Kumar, Prak Palassy Bangla,K.P.Bagchi and Company,Kolkata,1982,pg 106-107

${ }^{9}$ Mukhopadhya, Subodh Kumar, Prak Palassy Bangla,K.P.Bagchi and Company,Kolkata,1982,pg 109

${ }^{10}$ Rahim, M. A., Banglar Samajik O Sanskrit Itihas,Bangla Academy ,Dhaka,9182 translaed by Moh. Asaduzzaman and Fazle Rabbi ,pg 169-71
} 
anarchy prevailed among the members of the royal family. ${ }^{11}$ Lock died at the end of 1824 and on $25^{\text {th }}$ May ,1825 the government granted Lock's proposal and at Mubaraq Mahal a temporary school was started. ${ }^{12}$

Till 1831, only the traditional education was given to the youths of the Nizamat family. In 1831 a department was sanctioned by Captain Thresby to teach English. ${ }^{13}$ It should be noted that the Hindus and Muslim boys apart from the Nizamat family also came to this school and students from different parts of India used to come up there. Although the college was established to educate the boys of the Nizamat family, its progress was very poor. ${ }^{14}$ In 1835 Michail Hill visited the college and he was disappointed with the result of the college, especially with the result of the English. And he thought it was because of the National antipathy of the Hindoos. ${ }^{15}$ The agent of the governor made an enquiry for the reason of this backwardness of the Muslim students and he found that the lack of efficient inspector, admission of the outside students, more attention to the Hindu students and lack of efficient teachers were the main causes. ${ }^{16}$ So the Nizamat College could not fulfil its objectives. This college would have taken the initiative to spread education in the eastern part of India as a liberal institution. ${ }^{17}$

We can get a vivid picture of the Muslim education in Murshidabad by William Adam Hill's 3rd report(1838) regarding education. It states that there were 37 police stations in Murshidabad, among them 19 were at the town, Under 14 police station number of indigenous schools was 67.The teachers were Hindu. Only in one Bengali school there was a Muslim teacher. In these schools the number of students was 1082. Among them 998 were Hindu students and 82 were Muslim students. ${ }^{18}$

Report of Adam:

\begin{tabular}{|l|l|l|l|}
\hline Type of school & Number of schools & Hindu students & Muslim students \\
\hline Persian school & 17 & $\ldots \ldots$. & $\ldots \ldots$ \\
\hline Arabic school & 02 & 62 & 47 \\
\hline Bengali school & 62 & $\ldots \ldots$ & $\ldots \ldots$. \\
\hline Hindi school & 05 & 998 & 82 \\
\hline
\end{tabular}

The important thing is that in Arabic schools the number of Hindu students is more than the Muslim students. We see no noticeable change of this picture even in the information of Hunter.

\begin{tabular}{|l|l|l|}
\hline Year & Hindu students & Muslim students \\
\hline $1856-57$ & 668 & 23 \\
\hline $1870-71$ & 3881 & 990 \\
\hline $1881-82$ & 9297 & 3399 \\
\hline $1890-91$ & 15052 & 6586 \\
\hline
\end{tabular}

The above table proves that the percentage of educational progress of the Muslim students was decreasing .Though the Muslims were in majority in this district since 1901 the educational progress was not satisfactory.

\footnotetext{
${ }^{11}$. Nizamat College, Murshidabad,Under G.C.P.I. Correspondence,Section -2,pp 429

${ }^{12}$ Nizamat College ,Murshidabad,Under G.C.P.I. Correspondence,Section -2,pp 537

${ }^{13}$ General Department,Vol 95,Section 1,pp 265

${ }^{14}$ Das,Debashree Musrshidabad Jelai Sanskritik Mukttodhara: Oitihasik Samikka, Prabha Prakasani,24 Parganas,2002,pp 112

${ }^{15}$ Political Department,Vol 3,pp 289

${ }^{16}$ Das,Debashree,Musrshidabad Jelai Sanskritik Mukttodhara: Oitihasik Samikka, Prabha Prakasani,24 Parganas,2002,pp 115

${ }^{17}$ Das,Debashree Musrshidabad Jelai Sanskritik Mukttodhara: Oitihasik Samikka, Prabha Prakasani,24 Parganas,2002,pp 117

${ }^{18}$ District Gazzetteer,Berhampore,2003,11 ${ }^{\text {th }}$ Chapter,pp 409
} 
IRA-International Journal of Management E̊ Social Sciences

\begin{tabular}{|l|l|l|l|l|l|l|}
\hline Community & $\begin{array}{l}\text { Total } \\
\text { population }\end{array}$ & $\begin{array}{l}\text { Total } \\
\text { educated }\end{array}$ & Total male & $\begin{array}{l}\text { Total } \\
\text { educated } \\
\text { male }\end{array}$ & Total female & $\begin{array}{l}\text { Total } \\
\text { educated } \\
\text { female }\end{array}$ \\
\hline Hindu & 643474 & 53399 & 317979 & 50072 & 325495 & 3327 \\
\hline Muslim & 676899 & 19321 & 328928 & 18901 & 347971 & 420 \\
\hline
\end{tabular}

This table shows that the progress of education among the Muslim women was also very poor. ${ }^{19}$

\begin{tabular}{|l|l|l|l|l|l|l|l|}
\hline Religion & $\begin{array}{l}\text { Total } \\
\text { educated }\end{array}$ & Male & Female & $\begin{array}{l}\text { Total } \\
\text { English } \\
\text { educated }\end{array}$ & Male & Female & $\begin{array}{l}\text { Percentage } \\
\text { of } \\
\text { education }\end{array}$ \\
\hline Hindu & 56343 & 51187 & 5156 & 8844 & 8696 & 148 & 9 \\
\hline Muslim & 22392 & 21710 & 682 & 1421 & 1389 & 32 & 3 \\
\hline
\end{tabular}

The Krishnath College at Berhampore had a great contribution in extending western education in this district .Many students of this college are well established within the country and abroad also.The students had active participation in many fields. We can get a picture of Muslim educational progress from the percentage of pass out students of this college. Only 159 Muslim students in Honours (Arts) passed out from this college in the year 1867-1947 and only 29 students in Science passed out in the year 1910-1947. ${ }^{21}$

In the beginning of the British rule the whole Muslim society faced a disaster. ${ }^{22}$ Their life went into the darkness because of the British policies .In 1835 the British government announced English as the official language which was the beginning of western education in this country officially. ${ }^{23}$ In 1837 Persian was cancelled as an official language and it was declared that English and mother tong will be the official language. ${ }^{24}$ The Muslims showed their antipathy towards British educational policy and gradually they lagged behind, not only in education but socially and economically also. ${ }^{25}$ The Muslims directly blamed the British for their backwardness. Hunter in his Indian Musalmams says that 'They complain that they, who yesterday were the conquerors and governors of the land, can find no subsistence in it today For their degeneracy is but one of the results of our political ignorance and neglect .before he country passed under one rule ,the Muslims professed the same faith , ate the same food, and in all essentials lived the same life, as they do now .To this day they exhibit an intervals their old intense feeling of nationality and capability of war like enterprise; but in all other respects they are a race ruined under British rule." ${ }^{26}$ According to Hunter the causes for which the Muslims' downfall were 1.The Muslims were deprived from all the opportunities and British rule was responsible for it.2.They had feeling of being the ruling class and could not adjust with the new situation that the British brought.3. They lost their opportunity after English became the official language.4.they showed their antipathy towards the English language. ${ }^{27}{ }^{28}$ From the above discussion we can make the conclusion that the Muslims of this district are backward than the other communities and education is one of the main causes .During the Nawabi period they availed only the traditional system of education but with the changing situation they remained aloof and untouched for more than hundred years .Consequently the lagged behind in education, government employments and till our independence the scenario did not change. And it is clear that the British government policies as well as Muslim antipathy for Western education were the causes of this backwardness.

\footnotetext{
19 Gupta, Saumendra Kumar, Paribartaner Sandhane Murshidabader Banglalee Mussalman,Udar Akas,24 Parganas, 2013,pp 94-95

${ }^{20}$ Malley,L.S.S.O',Bengal District Gazetteers ,Murshidabad,Higher Education Department,Govt, ofWest Bengal ,Calcuta,1997,pp 299

${ }^{21}$ K,N.College 150 years Commemoration Volume ,1853-2003,Berhampore,2003,pp203-339

22 Khan, Muinuddin Ahmed, Muslim Dharma Sanskar Andolan,Sirajul Islam(ed.)Bangladesher Itihas,1704-1971,vol 3,Dhaka,1993,pp 93

${ }^{23}$ Masum, Moh Abdul Al, Banglar Muslim Samaje Adhunik Sikkhar Agragati,1885-1921,Dhaka,2007,pp 9

24 . Ahmed,Wakil,Unis Satake Bangalee Mussalmaner Chinta O Chetanar Dhara,Dhaka,1997, pp 438-439

${ }^{25}$ Ahmed,Wakil,Unis Satake Bangalee Mussalmaner Chinta O Chetanar Dhara,Dhaka,1997, pp 478

${ }^{26}$ Hunter,W.W.,The Indian Mussalmaqns,Dhaka,1999,pp 135

27 Hunter,W.W.,The Indian Mussalmaqns,Dhaka,1999 Chapter 4
} 


\section{References}

[1]. L.S.S. O'Malley,Bengal District Gazetteers ,Murshidabad,Higher Education Department,Govt, of West Bengal ,Calcuta,1997,pp 1

[2]. Sushil Chaudhury,Nababi Amale Murshidabad,Ananda Publishers,Kolkata 2011,pp 148

[3]. Abdul Karim ,Murshid Quli Khan And His Times,pp 238 quoted in M. A. Rahim Banglar Samajik O Sanskrit Itihas,Bangla Academy ,Dhaka,9182 translaed by Moh. Asaduzzaman and Fazle Rabbi ,pg209)

[4]. M. A. Rahim, Banglar Samajik O Sanskrit Itihas,Bangla Academy ,Dhaka,9182 translaed by Moh. Asaduzzaman and Fazle Rabbi , pg210)

[5]. M. A. Rahim, Banglar Samajik O Sanskrit Itihas, Bangla Academy ,Dhaka,9182 translaed by Moh. Asaduzzaman and Fazle Rabbi, pg 212

[6]. Nrittalal Basak ,History of Venacular Educatin in Bengal ,Ph.D. thesis -quoted in Debashree Das ,Musrshidabad Jelai Sanskritik Mukttodhara: Oiihasik Samikka, Prabha Prakasani,24 Parganas,2002,pg 62

[7]. Abdul Karim ,Murshid Quli Khan And His Times,pp 238 quoted in M. A. Rahim Banglar Samajik O Sanskrit Itihas,Bangla Academy ,Dhaka,9182 translaed by Moh. Asaduzzaman and Fazle Rabbi ,pg242

[8]. Subodh Kumar Mukhopadhya, Prak Palassy Bangla,K.P.Bagchi and Company,Kolkata,1982,pg 106-107

[9]. Subodh Kumar Mukhopadhya, Prak Palassy Bangla,K.P.Bagchi and Company,Kolkata,1982,pg 109

[10]. M. A. Rahim Banglar Samajik O Sanskrit Itihas,Bangla Academy ,Dhaka,9182 translaed by Moh. Asaduzzaman and Fazle Rabbi ,pg 169-71

[11]. Nizamat College ,Murshidabad,Under G.C.P.I. Correspondence,Section -2,pp 429

[12]. Nizamat College ,Murshidabad,Under G.C.P.I. Correspondence,Section -2,pp 537

[13]. General Department,Vol 95,Section 1,pp 265

[14]. Debashree Das ,Musrshidabad Jelai Sanskritik Mukttodhara: Oiihasik Samikka, Prabha Prakasani,24 Parganas,2002,pp 112

[15]. Political Department,Vol 3,pp 289

[16]. Debashree Das ,Musrshidabad Jelai Sanskritik Mukttodhara: Oiihasik Samikka, Prabha Prakasani,24 Parganas,2002,pp 115

[17]. Debashree Das ,Musrshidabad Jelai Sanskritik Mukttodhara: Oiihasik Samikka, Prabha Prakasani,24 Parganas,2002,pp 117

[18]. District Gazzetteer,Berhampore,2003,11 ${ }^{\text {th }}$ Chapter,pp 409

[19]. Saumendra Kumar Gupta,Paribartaner Sandhane Murshidabader Banglalee Mussalman,Udar Akas,24 Parganas, 2013,pp 94-95

[20]. L.S.S. O’Malley,Bengal District Gazetteers ,Murshidabad,Higher Education Department,Govt, ofWest Bengal ,Calcuta,1997,pp 299

[21]. K,N.College 150 yearsCommemoration Volume ,1853-2003,Berhampore,2003,pp203-339

[22]. Munuddin Ahmed Khan,Muslm Dharma Sanskar Andolan,Sirajul Islam(ed.)Bangladesher Itihas,1704-1971,vol 3,Dhaka1993,pp 93

[23]. Moh Abdul Al Masum,Banglar Muslim Samaje Adhunik Sikkhar Agragati,1885-1921,Dhaka,2007,pp 9

[24]. Wakil Ahmed,Unis Satake Bangalee Mussalmaner Chinta O Chetanar Dhara,Dhaka,1997, pp 438-439

[25]. Wakil Ahmed,Unis Satake Bangalee Mussalmaner Chinta O Chetanar Dhara,Dhaka,1997, pp 478

[26]. W.W.Hunter,The Indian Mussalmaqns,Dhaka,1999,pp 135

[27]. W.W.Hunter,The Indian Mussalmaqns,Dhaka,1999 Chapter 4. 